\title{
REVIEW TERHADAP BEBERAPA STUDI PILOT DARI KEWIRAUSAHAAN DAN INKUBASI BISNIS DI DUNIA
}

\author{
Lina Gozali ${ }^{1)}$, Maslin Masrom ${ }^{2)}$, Yuri T Zagloel ${ }^{3)}$, Habibah @ Norehan Haron ${ }^{2)}$, \\ Frans Jusuf Daywin ${ }^{1)}$ \\ ${ }^{1)}$ Program Studi Teknik Industri, Universitas Tarumanagara, Jakarta \\ ${ }^{2)}$ Universiti Teknologi Malaysia, Malaysia \\ ${ }^{3)}$ Universitas Indonesia, Depok \\ e-mail: ligoz@ymail.com
}

\begin{abstract}
ABSTRAK
Inkubasi bisnis adalah suatu sistem yang inovatif dan dirancang untuk membantu pebisnis mula-mula untuk membangun bisnisnya, terutama pebisnis di bidang teknologi. Tujuan dari penulisan ini adalah mengetahui lebih lanjut tentang studi pilot yang sudah dilakukan dalam bilang kewirausahaan dan inkubasi bisnis, sehingga kendala dan masalah yang dihadapi diketahui lebih dalam. Jumlah responden dalam pengumpulan data harus dievaluasi secara serius dan dipertimbangkan dari beberapa kasus yang sudah terjadi di dunia internasional. Methodologi dari naskah ini kajian studi pustaka dari beberapa jumlah responden yang digunakan dalam studi pilot dalam bidang kewirausahaan dan penelitian inkubasi bisnis. Hasil yang diperoleh dari review ini adalah jumlah terbesar dalam studi pilot bidang inkubasi bisnis dan kewirausahaan adalah 35 responden.
\end{abstract}

Kata kunci: Inkubasi bisnis, studi pilot, kewirausahaan.

\section{ABSTRACK}

The university business incubator (UBI) is an innovative system designed to assist entrepreneurs, particularly entrepreneurs in technology, in the development of new firms. The number of data or respondent by which is believed incubators should be evaluated internationally and seriously. The research method of this paper is a literature review to identify the research comparison study. This paper reviews literature on number of respondent of pilot, entrepreneurship and business incubator study. Whereas measures and concepts have been previously defined could improve the validity of the instrument, we further tested the scales for reliability. The research method of this paper is a literature review to identify the research comparison study. The result of this paper that the biggest number of respondents for Business Incubator Study in every country is 35, so the prediction of respondent for the future study will be more than 35 respondents.

Keywords: Pilot; Entrepreneurship; Business Incubator

\section{PENDAHULUAN}

Inkubasi bisnis dipandang penting dalam perkembangan perekonomian nasional karena mengembangkan kreasi nilai dari suatu usaha kecil menengah, di mulai dari awal dibentuknya usaha tersebut sampai pertumbuhan bisnis yang lebih besar. Masalah yang sekarang terjadi dan dihadapi oleh pembuat kebijaksanaan dan pelaku bisnis praktis adalah kurangnya penelitian dalam bidang inkubasi bisnis [1][2][3]. Inkubasi bisnis sendiri melingkupi kegiatan seleksi pemula bisnis, perkembangan bisnis, memperluas akses jaringan bisnis, menjadi penghubung bagi akses keuangan dan mampu memainkan peran yang baik di dalam jaringan-jaringan bisnis yang ada tersebut.

Naskah ini berusaha untuk memberikan kontribusi dalam hal studi pustaka dengan mengembangkan review terhadap proses penelitian dalam studi pilot bidang inkubasi bisnis. Tujuan dari naskah ini untuk membantu banyak peneliti bidang inkubasi bisnis, karena topik inkubasi bisnis terbilang baru muncul dalam situasi ekonomi dunia terutama di Indonesia.

Universitas Inkubasi Bisnis adalah suatu sistem yang inovatif yang mampu membantu para pengusaha, terutama pengusaha di bidang teknologi dalam pengembangan 
bisnis baru. Dengan menyediakan beberapa jasa dan bantuan bagi pebisnis mula-mula dan perusahaan yang baru dibentuk, inkubasi bisnis mencari jaringan bakat, teknologi, pemodal, pengetahuan yang efektif dalam mengangkat bakat mereka, untuk mempercepat perkembangan perusahaan-perusahaan baru, dan mempercepat komersialisasi teknologi tersebut [4].

Manager inkubasi bisnis memainkan peranan penting dalam membantu perkembangan bisnis, menciptakan lapangan kerja baru dan menghasilkan banyak perusahaan yang lulus dalam proses inkubasi bisnisnya, terutama membuat programprogram kewirausahaan yang baik serta penawaran-penawaran yang baik untuk jasa yang berwujud dan tidak berwujud. Inkubasi bisnis mampu mencapai tujuan utama dari perkembangan bidang ekonomi, transfer teknologi, mengembangkan kewirausahaan, dan penciptaan lapangan kerja [5].

Dalam penelitian sebelumnya tentang studi perbandingan dari beberapa inkubasi bisnis mengenai jumlah sampel riset dan analisis di dunia, diperoleh data bahwa jumlah tertinggi untuk responden adalah 358 responden untuk profit inkubasi bisnis dan 30 responden untuk universitas inkubasi bisnis di dunia [6]. Tapi fokus dari penelitian ini adalah berapa jumlah responden untuk studi pilot bidang kewirausahaan, inkubasi bisnis didunia. Penelitian ini dapat memberikan gambaran usaha yang diperlukan untuk menemukan responden bagi inkubasi bisnis di universitas-universitas negeri wilayah Indonesia untuk penelitian selanjutnya.

\section{LANDASAN TEORI \\ Inkubasi Bisnis}

Inkubasi bisnis dimaksudkan untuk mengurangi resiko kegagalan dalam tahap awal pembentukan perusahaan dan menghasilkan keuntungan yang signifikan serta membantu perkembangan perusahaan itu selanjutnya. Selanjutnya inkubators diharapkan untuk menciptakan sustainability, infrastruktur dan membantu menciptakan pebisnis tangguh untuk mendapatkan support yang sebaik-baiknya dalam menciptakan pebisnis yang sukses. Jantung dari inkubasi bisnis adalah pebisnis mula-mula [7].

Inkubasi bisnis bertindak sebagai alat yang aktif membantu perkembangan struktur bisnis baru dan membimbing pebisnis mula-mula untuk mengembangkan bisnisnya [8]. Fungsi utama dari inkubasi bisnis didasarkan pada kemampuannya menghasilkan lapangan kerja yang baru sehingga menjadi penting perannya dalam komunitas dan memimpin perkembangan ekonomi [9]. Elemen terpenting dalam inkubasi bisnis adalah jasa yang diberikan pada tahap awal pembentukan bisnis. Penelitian memperlihatkan bahwa jaringan bisnis adalah faktor yang sangat penting dalam kesuksesan pebisnis mula-mula [10].

Bagian administrasi bisnis menengah dan kecil di Amerika (2014), mendefinisikan accelerator bisnis sebagai unit bisnis yang menghasilkan bibit awal investasi bisnis, melingkupi pembimbingan bisnis, pendidikan bisnis sebelum masuk ke dunia bisnis nyata [11].

\section{Praktek Inkubasi Bisnis di Dunia}

Negara China pertama kali memulai inkubasi bisnis tahun 1987 di Wuhan, provinsi Hubei oleh Mentri Keilmuan dan Teknologi [12]. China saat itu sudah memulai jalan bertahap untuk masuk ke pasar ekonomi, maka inkubasi bisnis menjadi kunci utama dalam perkembangan ekonomi dalam pemerintahan negara China pada pertengahan dan akhir tahun 1990an. Pada waktu itu, strategi utama dari pemerintah China adalah menjaga perkembangan yang tinggi dari bidang ekonomi untuk mempromosikan perkembangan industri teknologi tinggi [13]. 
Di negara Jerman, boomingnya inkubasi bisnis dan teknologi dimulai tahun 1980an dan menyebar ke negara Austria [14][15]). Di Swiss, hanya ada beberapa diskusi yang menyangkut kebijakan teknologi di awal tahun 1990, tapi tidak memberikan hasil [16].

Di Australia, inkubasi bisnis mendapatkan dana dari Kementrian Industri, Pariwisata dan Sumber daya Negara Persemakmuran, Aus Industry adalah agen resmi yang ditunjuk dan bertanggung jawab untuk mengelola program-program inkubasi. Aus Industry menentukan definisi dan fungsi dari inkubasi bisnis sebagai perancangan fasilitas yang membantu bisnis yang baru berkembang menjadi mapan dan untung dengan menyediakan tempat, bimbingan, jasa, bantuan. Inkubasi bisnis dikenal untuk mengurangi resiko kegagalan pebisnis mula-mula. Hal ini untuk membantu terciptanya lapangan kerja baru dan membantu perkembangan ekonomi setempat [17].

Di Finlandia, mempelajari studi kasus dari 2 inkubator dipandang dari kebijakan manajemennya [18]. Inkubator yang dipelajari ini mengembangkan produk-produk lokal dan kesuksesan mereka hanya bisa dianalisa dalam pasar lokal. Cerita sukses tidak bisa digeneralisir. Pelaku bisnis harus berhati-hati dalam menerapkan kebijaksanaan karena setiap inkubator unik dan tidak sama penerapan manajemennya dengan inkubator yang lain. Adapun Abetti menemukan 4 studi kasus dalam 16 inkubasi bisnis di Finlandia untuk meneliti tentang berapa persen dari pelaku bisnis bisa bertahan dalam dunia usaha, berapa banyak lapangan kerja yang tercipta, dan berapa besar perkembangan penjualannya. Ternyata studi ini menemukan 95\% mampu bertahan dalam dunia usaha [19]. Inkubator bisnis menerima sedikit bantuan dana dari pemerintah tapi mampu menciptakan secara efektif lapangan-lapangan kerja yang memerlukan keahlian tinggi. Contohnya, pemerintah memberikan subsidi sebesar Euro 6.450 dimana dana ini dalam kategori rendah dibandingkan dengan biaya kesejahteraan per orang di Finlandia. Rata-rata tingkat penjualan berkembang $160 \%$ dari tahun ke tahun di wilayah Helsinki

Sebagai tambahan, Totterman dan Sten mempelajari studi kasus pada 3 inkubasi bisnis, 3 manager, 9 pemula bisnis, dan 9 perusahaan yang sudah lulus dari inkubasi bisnis. Mereka menemukan bahwa inkubasi bisnis membantu jaringan bisnis dari para perusahaan pemula dan memberikan keuntungan pada inkubator bisnis, sehingga inkubasi bisnis harus memberi focus dalam strategi jaringan bisnis daripada infrastruktur dan permodalan bisnis [20]. Selanjutnya Hytti dan Maki melakukan investigasi pada 113 perusahaan teknologi tinggi dengan tingkat pengembalian $83 \%$. Mereka menemukan bahwa perusahaan dari anak muda mendapat keuntungan besar dari inkubasi bisnis dibandingkan dengan perusahaan-perusahaan yang dahulu kurang puas dengan jasa yang diberikan oleh inkubasi bisnis. Periode inkubasi bisnis sangat flexible tergantung kebutuhan perusahaan pemula tersebut [21].

Studi selanjutnya tahun 2006 dari Zedwitz dan Grimaldi di Itali menemukan studi kasus dari 15 inkubasi bisnis. Hasil dari studi kualitatif menemukan bahwa jasa inkubasi bisnis seharusnya spesifik dalam setiap jenis bisnis tertentu dan portofolio jasa dari inkubasi bisnis harus disesuaikan dengan tujuan dari pembentukan inkubasi bisnis tersebut. Selanjutnya, manajemen inkubasi bisnis harus cukup berpengalaman dalam memenuhi kebutuhan dan tujuan inkubasi bisnis tersebut [22].

Di Inggris Wynarczyk dan Raine melakukan survey analisa dari 17 inkubasi bisnis. Studi dilakukan secara kualitative dan kuantitatif yang menunjukkan evaluasi inkubasi bisnis melaksanakan peran penting dalam membina bisnis pemula dan membuka lapangan kerja. Bantuan jasa yang dilakukan oleh inkubasi bisnis dan Pembina menunjukkan kondisi vital dalam membantu keberlangsungan perusahaan dan kemampuan pebisnis pemula bertahan dalam dunia usaha, terutama pada situasi pembentukan awal perusahaan pemula tersebut [23]. 
Studi selanjutnya yang dilakukan oleh McAdam di Irlandia dan Inggris mempelajari beberapa inkubasi bisnis selama 36 bulan. Peneliti menemukan sumber daya inkubasi bisnis menjadi factor penting dalam perkembangan pebisnis pemula pada tahap awal. Faktor penting lainnya yang ditemukan dalam kesuksesan pemula bisnis adalah jaringan bisnis [10].

Di Swiss, Thierstein and Wilhelm mempelajari studi kasus dari 9 inkubasi bisnis di Swiss. Studi menemukan bahwa perkembangan ekonomi regional tidak ditemukan dalam tujuan dari inkubasi bisnis. Hal ini bisa dijelaskan secara terpisah bahwa kondisi nyata ini terjadi karena pemilik inkubasi bisnis itu kebanyakan adalah pihak swasta di Swisss [17]. Kondisi di Spanyol, studi oleh Pena tahun 2004 menggunakan pendekatan kuantitatif mengevaluasi 114 perusahaan pemula dari 9 inkubasi bisnis mendata perkembangan penjualan, perkembangan kepegawaian dan perkembangan keuntungan. Studi menemukan bahwa keahlian manusia dari pebisnis menjadi sangat berpengarauh dalam peningkatan penjualan dan kepegawaian [24].

Di Turki, studi yang dilakukan oleh Akcomak dan Taymaz di tahun 2007 mempelajari 48 inkubasi bisnis dengan tingkat pengembalian 60\%. Studi difokuskan pada perkembangan penjualan, perkembangan kepegawaian, dan inovasi. Ditemukan fakta yang perkembangan penjualan dan kepegaiwan itu penting tapi tidak dalam hal inovasi [25]. Kemudian, Akcomak tahun 2009 menemukan bahwa pengalaman negara dalam membantu inkubasi bisnis yang benar dan tepat sebagai alat membantu menumbukan semangat kewirausahaan di negara-negara berkembang. Studi mempelajari kelemahan utama dari inkubasi bisnis di negara berkembang adalah: 1) Lebih berfokus pada jasa yang berwujud daripada yang tidak berwujud; 2) ketergantungan pada pemerintah; 3) kurangnya kemampuan manajemen dan orang yang berkompeten dalam mengelola inkubasi bisnis; 4) kurangnya perencanaan dan kreatifitas dalam memecahkan masalah [25].

\section{METODE PENELITIAN}

Menurut Connolly, perkembangan studi pustaka menyarankan data responden dari studi pilot seharusnya $10 \%$ dari jumlah sampel keseluruhan yang dituju [26]. Walaupun begitu Hertzog memperingatkan hal ini tidaklah hal yang mudah karena studi itu sangat dipengaruhi banyak faktor yang berpengaruh [27]. Hill tahun 1996 menyarankan jumlah responden untuk studi pilot adalah 10-30 orang [28], Julious tahun 1999 di bidang kedokteran menyarankan 12 peserta responden [29], Treece dan Treece tahun 1982 menyarankan 10\% dari keseluruhan jumlah sampel [30].

Methodologi dari penelitian ini hanya berdasarkan metoda studi pustaka. Studi perbandingan ini biasa dilakukan di semua bidang ilmu termasuk bidang keilmuwan sosial, studi perbandingan secara historis memainkan peran penting dalam perkembangan disiplin ilmu ilmiah. Selain itu studi perbandingan antar negara juga menjadi pertimbangan penting sehingga menimbulkan kesan pentingnya studi perbandingan ilmiah. Penelitian ini mempergunakan pendekatan survey untuk mendapatkan survey mendalam dan studi perbandingan ini adalah rancangan untuk mengembangkan pendekatan kualitatif [31].

\section{ANALISIS DAN PEMBAHASAN}

Dari Tabel 1 ditemukan fakta tentang studi perbandingan dari studi pilot bidang kewirausahaan dan inkubasi bisnis di dunia. Tabel tersebut menggambarkan informasi yang diperoleh dari beberapa peneliti yang mengembangkan studi yang relevan dengan subyek penelitian. Penemuan dari studi pustaka ini adalah beberapa naskah berhubungan dan studi kewirausahaan dilakukan oleh Latif mengenai produk penelitian dari universitas [32]. Suhud pada tahun 2013 meneliti tentang pendidikan kewirausahaan [33], Sandra meneliti tentang institusi pendidikan tinggi tentang kewirausahaan [34], Ahmed Miyaki 
tahun 2011 meneliti tentang industry jawa yang berkualitas [35], dan Loiz Hazelton tahun 2008 meneliti tentang industri perawatan [36].

Beberapa naskah juga meneliti tentang universitas dan pendidikan tinggi yaitu Latif [32], Sandra M Ajulu [34], serta Sang Suk Lee dan Jerome Osteryoung [37]. Beberapa naskah yang meneliti tentang inkubasi bisnis adalah Gaofetoge Ganamotse [38], Arumugam [39], dan Sang Suk Lee dan Jerome Osteryoung [37]. Naskah yang hanya meneliti tentang studi pilot inkubasi bisnis hanya Gaofetoge Ganamotse [38].

Responden dari studi inkubasi bisnis, fakta yang ditemukan dalam penelitian Arumugam mencapai 66\% dari jumlah sampel keseluruhan [39]. Sang Suk Lee mencapai $87 \%$ dari jumlah sampel keseluruhan, Jerome Osteryoung mencapai 43\% dari keseluruhan jumlah sampel [37]. Untuk studi pilot yang dilakukan oleh Gaofetoge Ganamotse mencapai 40\% dari jumlah sampel keseluruhan [38].

Fakta lain yang diperoleh dari tabel 1 adalah responden dari studi kewiruasahaan oleh Latif [32], Suhud [33], Ajulu [34], Maiyaki [35], dan Loiz [36] cukup banyak data yang bisa dikumpulkan, tapi untuk studi pilot inkubasi bisnis dan riset inkubasi bisnis sangat sedikit dan sulit untuk ditemukan perbandingannya.

\section{KESIMPULAN DAN SARAN}

Hasil kesimpulan dengan jelas mengindikasi tentang jumlah responden tentang studi kewirausahaan, industri dan universitas inkubasi bisnis sangat terbatas, dimana jumlah responden tertinggi adalah 68 untuk industri dan 46 untuk universitas inkubasi bisnis. Kesimpulan ini mendukung kesimpulan bahwa masih menjadi kesulitasn untuk menemukan penelitan tentang universitas inkubasi bisnis.

Banyak kesulitan ditemukan dalam penelitian inkubasi bisnis, dalam naskah ini menggambarkan studi perbandingan sebagai review studi inkubasi bisnis dan menggarisbawahi bahwa sangat terbatas data penelitian inkubasi bisnis yang bisa dikumpulkan. Penelitian ini memberikan kontribusi untuk membantu para pembuat kebijakan, pemerintah, pengelola universitas, peneliti, dalam membantu perkembangan studi inkubasi bisnis dengan menyediakan informasi berguna dari hasil studi perbandingan ini.

Tabel 1. Comparative Research of Pilot, Entrepreneurship and Business Incubator Studies

\begin{tabular}{|c|c|c|c|c|c|c|c|c|c|}
\hline Name of Researcher & Latif & Suhud & $\begin{array}{l}\text { Sandra M } \\
\text { Ajulu } \\
\end{array}$ & $\begin{array}{l}\text { Ahmed } \\
\text { Maiyaki }\end{array}$ & Lois Hazelton & G. Ganamotse & B. Arumugan & Sang Suk Lee & J. Osteryoung \\
\hline Year & 2015 & 2013 & 2010 & 2011 & 2008 & 2011 & 2014 & 2004 & 2004 \\
\hline Topics of Study & $\begin{array}{l}\text { University } \\
\text { Research } \\
\text { Product }\end{array}$ & $\begin{array}{l}\text { Entrepreneurial } \\
\text { Education } \\
\text { Education }\end{array}$ & $\begin{array}{l}\text { Higher } \\
\text { Education } \\
\text { Institute }\end{array}$ & $\begin{array}{l}\text { Service } \\
\text { Quality } \\
\text { Industry }\end{array}$ & Care Industry & $\begin{array}{l}\text { Business } \\
\text { Incubator }\end{array}$ & $\begin{array}{l}\text { Business } \\
\text { Incubator } \\
\text { Environment }\end{array}$ & $\begin{array}{l}\text { University } \\
\text { Business } \\
\text { Incubator }\end{array}$ & $\begin{array}{l}\text { University } \\
\text { Business } \\
\text { Incubator }\end{array}$ \\
\hline Country & Malaysia & Indonesia & South Africa & Malaysia & Australia & UK & India & Korea & USA \\
\hline Number of University & 5 & - & - & - & - & 23 & 53 & 39 & 46 \\
\hline Number of Respondent & 30 & 68 & 25 & 55 & - & 9 & 35 & 34 & 20 \\
\hline Methodology & Quantitative & Mixed & Quantitative & Quantitative & Quantitative & Quantitative & Quantitative & Quantitative & Quantitative \\
\hline
\end{tabular}

\section{DAFTAR PUSTAKA}

[1]. Bergek, A. \& Norrman, C. (2008) Incubator best practice: A framework. Technovation, 28, 20-28.

[2]. Hackett, A. M. \& Dilts, D. M. (2008) Inside the Black Box of Business Incubation. Journal of Technology Transfer, 33, 439-471. 
[3]. Albert, P. \& Gaynor, 1. (2001) Incubators: Growing Up, Moving Out: A Review of Literature CERAM. France: Sophia Antipolis.

[4]. Smilor, R. W., D. V. Gibson, and G. B. Dietrich (1990). "University Spin-Out Companies: Technology Startups from UT-Austin," Journal of Business Venturing 5, 63-76.

[5]. Hanadi, A. M., \& Busler, M. (2012). A Comparative Study of Incubators' Landscapes in Europe and the Middle East. European Journal of Business and Management, 4(10), 1-10.

[6]. Gozali, L., Maslin Masrom, Habibah @ Norehan Haron, Teuku Yuri M Zagloel (2015) Research Comparison among Business Incubator Research Sample and Analysis in The Worlds, International Conference Engineering Tarumanagara University 2015, October 22-23, 2015, Jakarta, Indonesia.

[7]. NEN, National Entrepreneurship Network. (2013), Guidelines-Metrics and Milestones For Successful Incubator Development, Wadhwani Foundation, Department of Science and Technology Government of India.

[8]. Rice, M. P., \& Matthews, J. (1995). Growing new ventures, creating new jobs: Principles and practices of successful business incubation. Westport, CT: Quorum Books.

[9]. Molnar, L., Adkins, D., Yolanda, B., Grimes, D., Sherman, H., \& Tornatzky, L. (1997). Business incubation works. Athens, Ohio: NBIA Publications.

[10]. McAdam, M., \& McAdam, R. (2008). High Tech Start-ups in University Science Park Incubators: The Relationship Between the Start-Up's Lifecycle Progression and Use of the Incubator's Resources. Technovation, 28 (5), 277-90.

[11]. US Small Business Administration, Definition of Small Business Incubators (2003). https://www.sba.gov/advocacy/innovation-accelerators-defining-characteristicsamong-startup-assistance-organizations . View July 2016.

[12]. Yan, Z (2003). The development history of science and technology incubators in China, In: Y, Zhao et al. (Eds) A Report on the Development of Science and Technology Incubators in China, PP 3-9. Xiamen University Press. China.

[13]. Xu, G. (2001) Preface, in: J Zhang (Ed). Chinese Science and Technology Incubators: Case Study and Development Strategies, PP. 1-3 Scientific and Technical Documents Publishing House. China.

[14]. Tödtling, F. (1990). Regional differences and determinants of entrepreneurial innovation-empirical results of an Austrian case study. In Technological Change in a Spatial Context (pp. 259-284). Springer, Berlin, Heidelberg.

[15]. Galley, H. (1997) Regionalwirtschaftliche Impulse durch Technologie-, Innovationsund Grunderzentren, Wirtschaftspolitische Blater, 5, 445-454

[16]. Thierstein, A., \& Wilhelm, B. (2001). Incubator, Technology and Innovation Centres in Switzerland: Features and Policy Implications. Entrepreneurship and Regional Development, 13 (4), 315-31.

[17]. Aus Industry (2003). Incubator Funding Scheme: Guide to Proponents, Canberra.

[18]. Autio, E., \& Klofsten, M. (1998). A Comparative Study of Two European Business Incubators. Journal of Small Business Management, 36, 30-43.

[19]. Abetti, P. A. (2004). Government-Supported Incubators in the Helsinki Region, Finland: Infrastructure, Results, and Best Practices. Journal of Technology Transfer, 29 (1), 19-40.

[20]. Totterman, H., \& Sten, J. (2005). Start-ups: Business Incubation and Social Capital. International Journal of Small Business, 23, 487-511.

[21]. Hytti, U., \& Maki, K. (2007). Which Firms Benefit Most from the Incubators. International Journal of Entrepreneurship and Innovation Management, 7 (6), 506-23. 
[22]. Von Zedtwitz, M., \& Grimaldi, R. (2006). Are Service Profiles Incubator-Specific? Results from an Empirical Investigation in Italy. Journal of Technology Transfer, 31 (4), 459-68.

[23]. Wynarczyk, P., \& Raine, A. (2005). The Performance of Business Incubators and Their Potential Development in the North East Region of England. Local Economy, 20 (2), 205-20.

[24]. Pena, I. (2004). Business Incubation Centers and New Firm Growth in the Basque Country. Small Business Economics, 22(3-4), 223-236.

[25]. Akçomak, I. S., \& Taymaz, E. (2007). Assessing the Effectiveness of Incubators: The Case of Turkey. In V. V. Ramani, and A. V. Bala Krishna (Eds.), Business incubation: an introduction. Hyderabad: Icfai University Press.

[26]. Cann, A. P., Connolly, M., Ruuska, R., MacNeil, M., Birmingham, T. B., Vandervoort, A. A., \& Callaghan, J. P. (2008). Inter-rater reliability of output measures for a posture matching assessment approach: a pilot study with food service workers. Ergonomics, 51(4), 556-572.

[27]. Hertzog, M. A. (2008). Considerations in determining sample size for pilot studies. Research in nursing \& health, 31(2), 180-191.

[28]. Hill, R. (1998). What sample size is "enough" in internet survey research. Interpersonal Computing and Technology: An electronic journal for the 21st century, 6(3-4), 1-12.

[29]. Julious, S. A., Campbell, M. J., and Altman, D. G. (1999). Estimating Sample Sizes for Continuous, Binary, and Ordinal Outcomes in Paired Comparisons: Practical Hints. Journal of biopharmaceutical statistics, 9(2), 241-251.

[30]. Treece, E. W., \& Treece, J. W. (1982). Elements of research in nursing (3rd ed.). St. Louis, MO: Mosby.

[31]. Ragin, Charles C. (1987) The comparative method: moving beyond qualitative and quantitative strategies. Berkeley (CA): University of California Press.

[32]. Latif, N. S. A., Abdullah, A., \& Jan, N. M. (2016). A Pilot Study of Entrepreneurial Orientation towards Commercialization of University Research Products. Procedia Economics and Finance, 37, 93-99.

[33]. Suhud, U., Purwana, D., \& Arafat, M. Y. (2015). Taking/receiving and giving (TRG): A comparison of two quantitative pilot studies on students' entrepreneurial motivation in Indonesia. International Journal of Research Studies in Management, 4(1).

[34]. Musengi-Ajulu, S. (2010). What do we know about the entrepreneurial intentions of the youth in South Africa? Preliminary results of a pilot study.

[35]. Maiyaki, A. A., \& Mokhtar, S. S. M. (2010). Determinants of customer behavioural responses: A pilot study. International business research, 4(1), 193.

[36]. Hazelton, L., \& Gillin, M. (2008). Corporate social entrepreneurship in the aged care industry: a pilot study.

[37]. Lee, S. S., \& Osteryoung, J. S. (2004). A comparison of critical success factors for effective operations of university business incubators in the United States and Korea. Journal of Small Business Management, 42(4), 418-426.

[38]. Ganamotse, G. N. (2011) A Conceptual Framework for Examining Selection Practices of Business Incubators, in 105h International Entrepreneurship Forum, Tamkeen, Bahrain, 9-11 January 2011, Page 1-2. University of Essex.

[39]. Arumugam, B. \& Ravindran, S. (2014) Success Factors of Incubatee Startups and the Incubation Environment Influencers. International Journal of Applied Business and Economic Research. Vol.12 (4), 1179-1193. 